\title{
Realization of Attitude and Engagement Markers in Students' Presentations
}

\author{
Alireza Afshar Mameghani \\ English Department, Shadegan Branch, Islamic Azad University, Shadegan, Iran \\ Seyed Foad Ebrahimi (Corresponding author) \\ English Department, Shadegan Branch, Islamic Azad University, Shadegan, Iran \\ E-mail: seyedfoade@yahoo.com
}

Received: 14-09-2016

Published: 01-03-2017
Accepted: 19-11-2016

doi:10.7575/aiac.ijalel.v.6n.2p.73
Advance Access Published: January 2017

URL: http://dx.doi.org/10.7575/aiac.ijalel.v.6n.2p.73

\begin{abstract}
Speakers use some interactional resources to convey their feelings or feedbacks to the prepositional content and attempt to build personal relationships with the listeners. Two of these resources are attitude and engagement markers and are used to express speakers' attitudes to preposition and to build relationships with listeners, respectively. This study intended to analyze the use of attitude and engagement markers in native English student presentations. To this end, eleven student presentations were extracted from the MiCASE corpus and analyzed to ascertain the use of attitude and engagement markers using Hyland (2005) taxonomy. The results showed that students try more to engage listeners and build relationships with them to ensure they are attentive and follow the presentations. The most common engagement markers were "you" and "see". These two markers engage speakers and listeners in an explicit manner. Attitude markers received less attention compared with engagement markers; the most common attitude marker found in the presentations was "interesting". The results of this study could be included in instructions on how students should use interactive resources such as engagement and attitude markers in their presentations.
\end{abstract}

Keywords: attitude, engagement, student presentations

\section{Introduction}

Swales (1990) points that discourse community has four characteristics namely "1) determined and fixed set of common public aims; 2) approaches and mechanisms for its members to communicate with each other; 3) one or more genres in the communicative assertions of its goals; and 4) a threshold level of members with an appropriate degree of relevant content and discursive expertise". Thus, according to Swales (1990), an example of discourse community is an academic community that contains several genres of communication. To access the community, members need to master these genres to be able to communicate their contributions with community members. An important feature of each genre is the communicative purpose that it serves, which is presented in the macro and micro structure of the genre. One of the academic genres which has been neglected by the researchers is student presentations. Thus, this study intends to focus on the use of attitude and engagement markers in this context. Attitude and engagement markers are two interactional metadiscourse markers.

Metadiscourse is sourced from the work of Malinowski (1927), who claimed that beside reflecting thought human language can create bonds of union between interlocutors. The term metadiscurse was coined by Zallig Harries (1959), while Williams (1981), Vande Kopple (1985), and Crismore (1989) have illustrated its aim and definition. Furthermore, Crismore (1984) highlights that the aim of metadiscourse is to "direct rather than inform the readers" (p. 280). Vande Kopple (1985) defines metadiscourse as "discourse that people use not to expand referential material, but to help the readers connect, organize, interpret, evaluate, and develop attitudes towards that material" (p. 84). Likewise, Hyland (2005) claims that "metadiscourse helps the communication to be more than just the exchange of information, goods or services and involves the personalities, attitudes and assumptions of those who are communicating."

Hyland classifies metadiscourse markers into two main classes: textual and interpersonal. The textual metadiscourse markers include five sub-classes, namely Endophoric Markers, Frame Markers, Logical Connectives, Code Glosses, and Evidentials, whereas the interpersonal metadiscourse markers help writers and speakers to present their attitudes and perspectives towards the propositional content of the text. These markers allow writers to engage the readers and listeners in the text by addressing them directly. Hyland (1998) also classifies the interpersonal metadiscourse markers into five sub-classes: Emphatics, Hedges, Person Markers, Relational Markers, and Attitude Markers.

Metadiscourse markers have been an area of concern for many researchers during the last two decades (Atmaca, 2016; Boshrabadi, Biria, and Zavari, 2014; Dafouz-milne, 2008; Hyland and Tse, 2004; Khedri, Ebrahimi and Chan, 2013; Khedri, Chan and Ebrahimi, 2013). 
Hyland and Tse (2004) studied the realization of metadiscourse markers in post-graduate dissertations from six disciplines, namely Public Administration, Computer Science, Applied Linguistics, Business Studies, Biology, and Electric Engineering. They found that in non- humanities disciplines, writers apply fewer metadiscourse markers than the humanities and social science disciplines. Their study highlights more widespread use of metadiscourse markers in the humanities and greater inter-disciplinary balance of interactive metadiscourse markers, however there is a higher proportion in the dissertations of science disciplines. In addition, there is evidence that engagement markers and boosters were approximately similar across disciplines, but hedges were found two times as often in the humanities disciplines and self-mentions were roughly four times more frequent. Transitions were realized in the humanities disciplines but emphatics were realized less in the humanities disciplines. While evidentials offers support for the position of writers, this marker was less evident in the non-humanities disciplines; primarily, this was used in Biology to present the link between the study and the existing literature in the field.

Dafouz-milne (2008) studied the role of metadiscourse markers in the construction and attainment of persuasion; she implied a cross-linguistic perspective and chose two elite newspapers; the British The Times and the Spanish El País. Her work involves an analysis of a corpus of 20 opinion columns from each newspaper and suggests that interpersonal and textual metadiscourse markers were realized in both set of columns. She found variations concerning the distribution and composition of the markers, particularly in the case of certain textual categories.

Furthermore, Boshrabadi, Biria, and Zavari (2014) investigated the function of metadiscourse markers used in Persian and English Economic news reports. They analyzed 10 news reports (five from each language) extracted from the Economic sections of newspapers published in 2013-2014 in Iran and the United States. They adopted Kopple's (1985) taxonomy to analyze the news reports and reported that textual markers were more repeated in Persian Economic news reports than in English Economic news reports. In relation to the interpersonal markers, they found that these markers were more frequent in English Economic news reports. Their research also highlighted that the differential use of metadiscourse markers in Persian and English Economic news reports could be discussed based on the culture-specific norms governing the development and organization of discourse.

Atmaca (2016) intended to find the possible similarities and differences concerning the use of hedges between M.A. theses and Ph.D. dissertations from the field of English Language Teaching. Accordingly, 10 M.A. theses and 10 Ph.D. dissertations were analyzed. Content analysis was used for various hedging tools, which were nearly double in the Ph.D. dissertations compared to those in the M.A. theses. They also found that modals, followed by passivization, are the most common form of hedging, whereas nouns are the least frequent hedging type; this could account for some of the differences between novice and experienced writers.

Khedri, Ebrahimi and Chan (2013) investigated the use of interactive metadiscourse markers in the results and discussion sections of research articles from four disciplines. They analyzed four research article results as well as discussion sections from each discipline, adopting Hyland (2005) taxonomy and pointing that there are some crossdisciplinary variations in the use of interactive metadiscourse markers. These authors also carried out a study (2013) on the use of interactive metadiscourse markers in research article abstracts from two disciplines of Applied Linguistics and Economics. Once again Hyland's (2005) taxonomy was utilized, with noticeable socio-rhetorical variations in the ways Applied Linguists and Economists construct their argumentations through interactive metadiscourse features being identified.

The literature review indicates that most of the studies have focused on the realizations of discourse markers in the written academic texts, especially research articles and their rhetorical sections. Thus, this study aims to study the realizations of attitude and engagement markers in student presentations.

\section{Methodology}

2.1 Corpus

This study is conducted on 11 English native student presentations, which have been extracted from the MiCASE corpus. The presentations are extracted in a transcribed form. The characteristics of the data are tabulated as follows:

Table 1. Particulars of the corpus

\begin{tabular}{ccccccc}
\hline No. & Words & Time & Students & Speakers & Title & $\begin{array}{c}\text { Academic } \\
\text { Division }\end{array}$ \\
\hline 1 & 9791 & 69 & 20 & 12 & $\begin{array}{c}\text { Second Language Acquisition } \\
\text { Student Presentations }\end{array}$ & Humanities \\
\hline 2 & 15153 & 99 & 7 & 6 & $\begin{array}{c}\text { Bilingualism Student } \\
\text { Presentations }\end{array}$ & Humanities \\
\hline 3 & 12354 & 72 & 17 & 11 & $\begin{array}{c}\text { Multicultural Issues in } \\
\text { Education Student } \\
\text { Presentations }\end{array}$ & $\begin{array}{c}\text { Social Sciences } \\
\text { and Education }\end{array}$ \\
\hline 4 & 6575 & 51 & 40 & 18 & $\begin{array}{c}\text { Chemistry Discussion Section } \\
\text { Student Presentations }\end{array}$ & $\begin{array}{c}\text { Physical } \\
\text { Sciences and } \\
\text { Engineering }\end{array}$ \\
\hline 5 & 22596 & 123 & 23 & 12 & Architecture Critiques & Humanities \\
\hline
\end{tabular}




\begin{tabular}{ccccccc}
6 & 12345 & 78 & 20 & 15 & $\begin{array}{c}\text { Brazilian Studies Student } \\
\text { Presentations }\end{array}$ & $\begin{array}{c}\text { Social Sciences } \\
\text { and Education }\end{array}$ \\
\hline 7 & 10585 & 66 & 30 & 26 & $\begin{array}{c}\text { Community Change Student } \\
\text { Presentations }\end{array}$ & $\begin{array}{c}\text { Social Sciences } \\
\text { and Education }\end{array}$ \\
\hline 8 & 5241 & 32 & 8 & 5 & $\begin{array}{c}\text { Rehabilitation Engineering } \\
\text { and Technology Student } \\
\text { Presentations }\end{array}$ & $\begin{array}{c}\text { Physical } \\
\text { Sciences and } \\
\text { Engineering }\end{array}$ \\
\hline 10 & 22223 & 155 & 11 & 10 & $\begin{array}{c}\text { Nursing Student } \\
\text { Presentations }\end{array}$ & $\begin{array}{c}\text { Biological and } \\
\text { Health Sciences }\end{array}$ \\
\hline 11 & 17228 & 121 & 25 & 18 & $\begin{array}{c}\text { Teaching Biochemistry } \\
\text { Black Media Student } \\
\text { Presentations }\end{array}$ & $\begin{array}{c}\text { Social Sciences } \\
\text { and Education }\end{array}$ \\
\hline Total & 143373 & 932 & 218 & 146 & Biological and \\
Health Sciences
\end{tabular}

\subsection{Framework}

To analyze the corpus for the attitude and engagement markers, Hyland's (2005) taxonomy was adopted. To Hyland (2005),"'attitude markers show the writer's influential, not epistemic, viewpoint and attitude towards propositional content. Using attitude markers, the writer expresses his or her personal feelings such as agreement, surprise, obligation, importance, and so on. Attitude markers could be characterized through lexical choices such as attitude verbs (agree, prefer), sentence adverbs (unfortunately, hopefully), and adjectives (appropriate, remarkable). Engagement markers address readers clearly, either to attract their attention or engage them as discourse participants in the use of expressions such as note that, consider, you can see that, etc".

\subsection{Procedure}

To analyze the corpus and reach tabulated results, the following procedures were established. First, the student presentations were extracted and save in Microsoft Word Format 2003. Second, the researchers read the class presentations to get the gist of the presentations. Third, the presentations were searched for attitude and engagement markers. Fourth, to mitigate the false detection of markers, three presentations were analyzed by a $\mathrm{PhD}$ holder in Applied Linguistic and agreement was reached upon analysis. Finally, the results were tabulated and discussed.

\section{Results and discussion}

The corpus was analyzed for the realizations of attitude markers and engagement markers. The results are presented in Table 2.

Table 2. Frequency of attitude and engagement markers per 1000 words in student presentations

\begin{tabular}{llll}
\hline & Word count & Frequency & Frequency per 1000 words \\
\hline Attitude Markers & 143373 & 685 & 4.77 \\
\hline Engagement Markers & 143373 & 4208 & 29.35
\end{tabular}

As is evident in Table 1, students showed six times more inclination towards using engagement markers compared to attitude markers. The results are in line with the findings reported by Shi and Han (2014) and in contrast with Khedri et al. (2015). The similarity of the findings of this study with those of Shi and Han (2014) could be discussed based on the similarity in the academic level of developers of both corpora. In both studies corpus chosen for exploration was developed by students. Therefore, it could be concluded that in texts, whether spoken or written, students prefer to engage the reader more that expressing their attitudes towards the content. This might suggest that students do not believe themselves to have the necessary ability to comment or present their attitudes. The differences between the results of this study and the findings presented by Khedri et al. (2015) are rooted in the differences in the genres analyzed. These genre imposed differences originate from the fact that in genres such as research articles, the writer reports experiment that he/she has conducted; consequently, they feel brave enough to presents their fillings, attitudes concerning the content of research article. In genres such as student presentations on the other hand, students merely report the content and comments and attitudes are only reported occasionally.

\subsection{Attitude Markers}

This marker (Example 1) helps the speaker to present his/her viewpoint and attitude towards the content of the presentation. The speaker also uses this marker to convey his/her feelings, obligations and frustrations (Hyland 2005).

Example 1: "and that takes us to the conclusions, which, we reached two one for the no- native speakers and one for non-native speakers. for native speakers we said that in general, they used closures appropriate with the context of the situation, and uh, with non-native speakers, and, we kinda base our, conclusions more on the open ended questions than on the, multiple choice questions" ........ 
According to the evidence in Table 3 , the most frequent linguistic realizations of attitude markers are evaluative adjectives (important, interesting) (Example 2-4). Such adjectives help speakers to have more subjective presentations. To Solar (2002), these adjectives insert ether positive or negative judgment or comment to the modified noun; they show the "speakers' favourable or unfavourable positions towards the modified nouns" (Soler, 2002, p. 155).

Example 2: "okay, somebody who has a three probably only answered yes to one thing maybe, to another representative of that so, and there's, you know there's definitely variability you know there's, people who, it's really important to them to, to maintain language A and yet they have a pretty low theoretical affiliation but there is a correlation of um, uh, this is th- this- these are the questions (xx) um"...

Example 3: "yeah, i think and then time for questions, and then there's uh... (i don't) (have this) it's in my bag... um, the one other interesting thing is and i already talked about this in my other presentation but um there was this distribution lemme just find that,"

Example 4: "i think, was that um we expected the native speakers to have a wider range of use of their pragmatic knowledge and have more, um, types of responses available to them, than the non-native speakers, and as you can see, the people who did, come in with different types of responses"

Table 3. Frequency and percentage of the attitude markers subcategory

\begin{tabular}{lll}
\hline & Frequency of occurrence & $\begin{array}{l}\text { Percentage of } \\
\text { occurrence }\end{array}$ \\
\hline Evaluative Adjective & 620 & 90 \\
\hline Evaluative Adverb & 65 & 10 \\
\hline
\end{tabular}

The results presented above could suggest that the nature of the student presentations encourages speakers to show little attention towards the use of attitude markers. This is rooted in the minimal background knowledge students have regarding the topic of presentation. It is also suggested that students prefer to deviate a big portion of attitude markers frequency to the realization of evaluative adjectives. These adjectives give subjective taste to the presentations.

\subsection{Engagement Markers}

Engagement markers (Example 5) are used to engage the listener or reader as a participant in the discourse. This marker was realized 29.35 times per 100 words in student presentations, which is much higher than the figures reported by Khedri et al. (2015) and Akbas (2012). In both of these studies, authors analyzed written discourse. Thus, the difference could be discourse oriented. In student presentations, the speaker and listener are together in the same place and therefore speakers need to catch the attention of listeners to follow their presentations. In written discourse, writers are developing the text that will be read at a later point in time. As such, they do not feel the need to engage the readers and attract their attention to the same extent as is needed in spoken discourse.

Example 5: "because, i um, i want, i want to be considered Latino and i feel like this is, like, validates me in some way basically what they're saying so they, he says, because i don't look like a Latino person, since i'm not brown, uh let's see, are they wha- are your kids gonna be you know Hispanic, and so i wanna know you know i wanna speak Spanish basically".

The realizations of engagement markers in student presentations showed that students used discourse oriented linguistic realizations to realize engagement markers. Among the most common realizations were "let's, look at, see, remember, find, consider" (Example 6-8). These realizations could be expected in spoken discourse, and therefore greater use of engagement markers in spoken discourse might be justified based on this fact.

Example 6: "and one of the things he does says is that if you're gonna look at a language contact, phenomenon in native North America or the Americas when dealing with n- with uh Indian languages, um one really has to look at the histories because, there's so much history of transplantation of removal".

Example 7: "when we discuss the test you'll see that we were controlling for status in the two tests that we used"...

Example 8: "you might consider that a_most people probably won't ask for anymore information."

From the above findings, it can be determined that students prefer to use more engagement markers due to the nature of spoken discourse. As stated in Examples 6-8, the linguistic realization of this marker was also reported to be discourse based. 


\section{Conclusion and implications}

This study has primarily investigated the realization of engagement and attitude markers in student presentations. To Hyland (2005), these markers help to produce subjective discourse; they highlight the attitude of the speaker regarding the content of the discourse and the speakers' intention to engage the listener in the discourse.

The results reported in this study lead to the following conclusions. In student presentations, students do not feel the necessity of presenting their attitudes regarding the content of the presentations due to the fact that they are reporting information that might already be validated and considered as a fact. They might not have sufficient content background knowledge to evaluate the content. It has also been reported that the realization of this marker was mostly used to express feelings regarding the content itself through the evaluative adjectives. Thus, it can be concluded that in student presentations, this marker is not highly stressed and such a practice is not deemed necessary.

With regards to the use of the engagement marker, students showed greater attention towards the use of this marker in order to engage the listener throughout the discourse. Thus, it can be concluded that in spoken discourse such as student presentations, speakers believe it is important to engage the listeners as participants in the discourse to be able to continue their discourse while having the listener following. Consequently, such a use of engagement markers seems to be discourse imposed.

In terms of implications, the results of this study can act as a guide to add to the knowledge of students and instructors concerning how to present their attitudes towards the content of presentations and also how to engage the participants in the discourse to encourage them to follow presentations better and ensure they are focused on the content.

Because the student presentation genre has received little attention, we can suggest further studies that focus on other linguistic features and also focus on the movements and steps of a presentation's structure.

\section{References}

Akbas, E. (2012). Exploring metadiscourse in master's dissertation abstracts: Cultural and linguistic variations across postgraduate writers. International Journal of Applied Linguistics \& English Literature, 1(1), 12-26.

Atmaca, C. (2016). Comparison of hedges in ma theses and ph. D. Dissertations in elt. Journal of World of Turks/Zeitschrift für die Welt der Türken, 8(2).

Boshrabadi, A. M., Biria, R., \& Zavari, Z. (2014). A Cross Cultural Analysis of Textual and Interpersonal Metadiscourse Markers: The Case of Economic Articles in English and Persian Newspapers. Advances in Language and Literary Studies, 5(2), 59-66.

Crismore, A. (1984). The rhetoric of textbooks: Metadiscourse. Journal of Curriculum Studies, 16 (3), $279-96$.

Crismore, A., \& Farnsworth, R. (1989). Mr. Darwin and his readers: Exploring interpersonal metadiscurse as a dimension of ethos. Rhetoric Review, 8, 91-112.

Dafouz-Milne, E. (2008). The pragmatic role of textual and interpersonal metadiscourse markers in the construction and attainment of persuasion: A cross-linguistic study of newspaper discourse. Journal of Pragmatics, 40, 95-113.

Harris, Z. (1959). The Transformational Model of Language Structure. Anthropological Linguistics 1(1): $27-29$.

Hyland, K. (1998). Persuasion and context: The pragmatics of metadiscourse. Journal of Pragmatics. Vol. 30, 437-455.

Hyland, K. (2005). Metadiscourse: Exploring interaction in writing. London: Continuum.

Hyland, K., \& Tse, P. (2004). Metadiscourse in academic writing: A reappraisal. Applied Linguistics, 25(2), $156-177$.

Khedri, M., Ebrahimi, S. J., \& Chan, S. H. (2013). Interactional metadiscourse markers in academic research article result and discussion sections. 3L: The Southeast Asian Journal of English Language Studies, 19(1), 65-74.

Khedri, M., Chan, S. H., \& Ebrahimi, F. (2013). An exploration of interactive metadiscourse markers in academic research article abstracts in two disciplines. Discourse Studies, 15(3), 319-331.

Khedri, M., Chan, S. H., \& Tan, H. (2015). Interpersonal-driven features in research article abstracts: cross-disciplinary metadiscoursal perspective.Pertanika Journal of Social Sciences \& Humanities, 23(2), 303-314.

Malinowski, B (1927). Problem of Meaning in Primitive Languages. In: Ogden, C. K. / Richards, I. A. (edd.), (21927), Meaning of Meaning. New York: Harcourt, 296 -336.

Shi, W., \& Han, J. (2014). Research on Writing Samples from the Perspective of Metadiscourse. English Language Teaching, 7(11), 151.

Soler, V. (2002). Analysing adjectives in scientific discourse: an exploratory study with educational applications for Spanish speakers at advanced university level. English for Specific Purposes, 21(2), 145-165.

Swales, J. (1990). Genre Analysis. English in Academic and Research Settings. Cambridge: Cambridge University Press.

Vande Kopple \& W. J. (1985). Some exploratory discourse on metadiscourse. College Composition and Communication. Vol. 36, 82-93.

Williams, J. (1991). Style: Ten lessons in clarity and grace. Boston: Scott Foressman. 